\title{
Salmon lice infection in wild salmonids in marine protected areas: Comment on Serra-Llinares et al. (2014)
}

\author{
P. A. Jansen ${ }^{1, *}$, E. Brun ${ }^{1}$, E. Skjerve ${ }^{2}$ \\ ${ }^{1}$ Norwegian Veterinary Institute, PO Box 750, 0106 Oslo, Norway \\ ${ }^{2}$ NMBU School of Veterinary Science, Sea Lice Research Centre, PO Box 8146, 0033 Oslo, Norway
}

\begin{abstract}
Serra-Llinares et al. (2014; Aquacult Environ Interact 5:1-16) analysed the association between the estimated production of salmon louse copepodites in salmon farms and lice infection levels in wild salmonids. The authors argued that $41 \%$ of the variance observed in the number of salmon lice on wild fish is explained by lice production in nearby salmon farms. The correlation identified by Serra-Llinares et al. (2014; their Fig. 3) could, however, be explained by an effect of temperature variation in time and space, rather than a causal relationship between salmon farming and lice infection in wild salmonids.
\end{abstract}

KEY WORDS: Temperature $\cdot$ Seasonal infection dynamics $\cdot$ Farmed salmon $\cdot$ Correlation $\cdot$ Spatial and temporal covariance $\cdot$ Lepeophtheirus salmonis

\section{Introduction}

Serra-Llinares et al. (2014) analysed the association between estimated salmon louse production in salmon farms (focusing on copepodites, the infective stage of Lepeophtheirus salmonis) and lice infection levels in the wild salmonids Salmo trutta and Salvelinus alpinus. Using correlation and regression analyses, they found that the estimated copepodite production in nearby salmon farms explained $41 \%$ of the variance in the mean abundance of lice on wild fish. The authors concluded that 'results from this analysis support the hypothesis of a positive correlation between production of live infective stages from fish farms and the mean abundance of lice on wild fish in surrounding areas' (Serra-Llinares et al. 2014, p. 11). Serra-Llinares et al. (2014) deduced that successful protection of wild salmonids in small fjords is 'strongly dependent on the production pattern of the aquaculture industry in the surrounding area' (p. 1). Here we question the design of the correlation and

\footnotetext{
${ }^{*}$ Corresponding author: peder.jansen@vetinst.no
}

regression analyses presented by Serra-Llinares et al. (2014) and suggest an alternative explanation for the close relationship between lice numbers in wild salmonids and adjacent salmon farms.

\section{Relationship between lice of farm origin and infection on wild fish}

Serra-Llinares et al. (2014) correlated lice abundance in wild salmonids with estimates of daily copepodite production in nearby salmon farms (Fig. 3 in Serra-Llinares et al. 2014). Copepodite production in farms was estimated using the reproduction model of Stien et al. (2005), with temperature as a determinant of the per capita reproductive rate per female louse. In this model, an increase in temperature results in an increase in lice production. Estimated per capita louse reproduction was then multiplied by reported mean counts of adult female lice per fish and numbers of farmed fish to compute farm specific esti-

() The authors 2016. Open Access under Creative Commons by Attribution Licence. Use, distribution and reproduction are unrestricted. Authors and original publication must be credited. 
mates of copepodite production. The adult female lice counts reported from farms and used in the calculations of Serra-Llinares et al. (2014) fluctuate seasonally with temperature (Jansen et al. 2012). Inclusion of the temperature effect in the reproduction model increases the magnitude of seasonal fluctuation in in-farm copepodite production. The resulting steep seasonal peaks in estimates of copepodite production in farms are apparent in Fig. $2 b$ in SerraLlinares et al. (2014).

A higher mean abundance of salmon lice on salmonids caught inside the smaller 'National Salmon Fjords' (Table 3 in Serra-Llinares et al. 2014) was observed in all summer samples (Period 2) compared to spring samples (Period 1) for any given fjord location and year. The observed pattern suggests similar seasonal dynamics in lice infections in both wild and farmed fish, i.e. annual cycles of high lice abundance in summer/autumn and low lice abundance in winter/spring. Schram et al. (1998) observed the same temporal pattern in lice numbers on wild sea trout Salmo trutta in areas with no salmon farming. Additionally, there seems to be a spatial component in lice abundance on wild fish, suggesting lower lice numbers in the north (Altafjord) (Serra-Llinares et al. 2014). A similar spatial pattern in lice abundance was observed in farmed fish (Jansen et al. 2012). The high reported 'squared Pearson correlation coefficient' $\left(r^{2}=0.409\right)$ between lice numbers in samples of wild salmonids and daily copepodite production in salmon farms (Serra-Llinares et al. 2014) could, therefore, be caused by a spatio-temporal covariance in lice abundance on farmed and wild fish. The pairwise timing and location of the correlated data sets thus reflect the spatio-temporal population dynamics of salmon lice, which are closely related with temperature (Schram et al. 1998, Stien et al. 2005, Jansen et al. 2012). It is therefore necessary to account for the effect of temperature to establish whether there is an additional effect of copepodite production in nearby salmon farms when analyzing factors that affect lice numbers in wild salmonids.

The association between lice abundance in farmed and wild fish appears to be weaker when the statistical analysis includes temperature (Helland et al. 2012). Helland et al. (2012) analysed data from the same source as Serra-Llinares et al. (2014), but for the years 2004 to 2010 instead of 2010 to 2012. In contrast to Serra-Llinares et al. (2014), Helland et al. (2012) were not able to predict lice numbers in wild

Editorial responsibility: Susanne Schüller, Oldendorf/Luhe, Germany salmonids by lice densities in nearby salmon farms. Farm lice densities were, however, associated with the presence of lice on wild salmonids (Helland et al. 2012). Comparing the 2 studies, it seems that Serra-Llinares et al. (2014) may have overestimated the support their data provides for farm origin lice being a main source of lice infection in wild salmonids.

\section{Concluding remarks}

The effect of salmon lice of farm origin on stocks of wild salmonids is a contentious issue with political consequences for the future of salmonid aquaculture in Norway. Serra-Llinares et al. (2014) argued that the results from their analysis 'support the hypothesis of a positive correlation between the production of lice infective stages from fish farms and the mean abundance of lice on wild fish in surrounding areas' (p. 11), but temperature may well be a confounding factor in this association. If temperature is a confounder and there is no additional effect of farm origin lice as a factor that affects lice numbers in wild fish, then we would argue that there is no support in Serra-Llinares et al. (2014) for the notion that lice of farm origin are a main source of infection in wild salmonids.

\section{LITERATURE CITED}

Helland IP, Finstad B, Uglem I, Diserud OH and others (2012) Hva avgjør lakselusinfeksjon hos vill laksefisk? Statistisk bearbeiding av data fra nasjonal lakselusovervåking, 2004-2010. NINA Rapport 891, Norwegian Institute for Nature Research, Trondheim

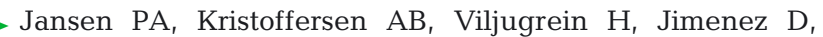
Aldrin M, Stien A (2012) Sea lice as a density-dependent constraint to salmonid farming. Proc R Soc Lond B Biol Sci 279:2330-2338

> Schram TA, Knutsen JA, Heuch PA, Mo TA (1998) Seasonal occurrence of Lepeophtheirus salmonis and Caligus elongatus (Copepoda: Caligida) on sea trout (Salmo trutta), off southern Norway. ICES J Mar Sci 55:163-175

Serra-Llinares RM, Bjørn PA, Finstad B, Nilsen R, Harbitz A, Berg M, Asplin L (2014) Salmon lice infection on wild salmonids in marine protected areas: an evaluation of the Norwegian 'National Salmon Fjords'. Aquacult Environ Interact 5:1-16

Stien A, Bjørn PA, Heuch PA, Elston DA (2005) Population dynamics of salmon lice Lepeophtheirus salmonis on Atlantic salmon and sea trout. Mar Ecol Prog Ser 290: 263-275

Submitted: June 22, 2015; Accepted: April 7, 2016

Proofs received from author(s): May 10, 2016 